\title{
TWO NEW CONUS SPECIES FROM OFF BARBADOS, LESSER ANTILLES (GASTROPODA, CONIDAE)
}

\author{
by \\ E. WILS \& R. G. MOOLENBEEK \\ Institute of Taxonomic Zoology (Zoölogisch Museum), University of Amsterdam, The Netherlands
}

\begin{abstract}
Conus sanderi n. sp. and Conus bunti n. sp. are described from deeper water (155-180 m), dredged off Barbados. Both are related to $C$. villepinii Fischer \& Bernardi from the same area.
\end{abstract}

\section{INTRODUCTION}

Some deeper water Conidae, dredged off Barbados and other islands of the Lesser Antilles, were mentioned by Dall (1886: pl. IX fig. $8 ; 1889$ : 67-70) in the "Blake Report". They include Conus mazei Deshayes, 1874, C. agassizii Dall, 1886, C. villepinii Fischer \& Bernardi, 1857, and $C$. centurio Born, 1778.

Clench (1942, 1951) and Clench \& Bullock (1970) discussed the Conidae of the Western Atlantic. Nowell-Usticke (1968) and Lozet \& Pétron (1977: 94-111) also gave data on deeper water Conidae from the Lesser Antilles.

Some Conidae dredged on the north coast of South America were described by Van Mol (1973) and Van Mol et al. (1967, 1971).

Notwithstanding the collections made by the "Blake" near Barbados, two new species of Conus were discovered in recent years from dredgings with the research vessel "Martlet" of the Bellairs Research Institute of McGill University, St. James, Barbados.

Some specimens were shown to the first author in October 1976, more material was received in later years. In 1978, sufficient material was available to study and describe these new species.

\section{Conus sanderi n. sp.}

Figs. 1-6, 10.

Description of holotype. - Shell small, rather slender. Body whorl nearly straight, somewhat convex towards the shoulder. Surface smooth and shiny, with 9 spiral grooves on the base. Shoulder angulated. Aperture straight and narrow. Spire concave, 9 whorls. The postnuclear whorls have $4-5$ striae. The first 3 postnuclear whorls have axial (tubercle-like) sculpture on the sides, weakening progressively.

Measurements: length $21.1 \mathrm{~mm}$, width 11.2 $\mathrm{mm}$, aperture $18.1 \mathrm{~mm}$.

Colour: The main colour is yellowish orange. The upper part of the body whorl has zigzag streaks, which continue on the spire as darker markings. In the middle is a broad light band with two spiral lines of brown spots. Below this band an alternating white and brown spotted line is present. On the base are some irregular light blotches.

Paratypes. - Shell length up to $23 \mathrm{~mm}$ (table I), rather slender, width about half of total length. About 8-12 spiral grooves on the base. The spire has $21 / 2-3$ smooth, brownish nuclear whorls, 7-9 postnuclear whorls of which the first $2-3$ have axial sculpture on the sides, weakening progressively. The spire of paratype 10 is represented in fig. 10 by a SEM photograph.

The main colour varies from pale to bright yellowish orange. There is a broad light band over the middle of the body whorl, sometimes ornamented on the sides by rows of irregular brown spots.

Type locality. - Off St. James, west Barbados, $155-180 \mathrm{~m}$.

Deposition of type material. - The holotype and 11 paratypes are in the collection of the Zoölogisch Museum Amsterdam (ZMA). Six 

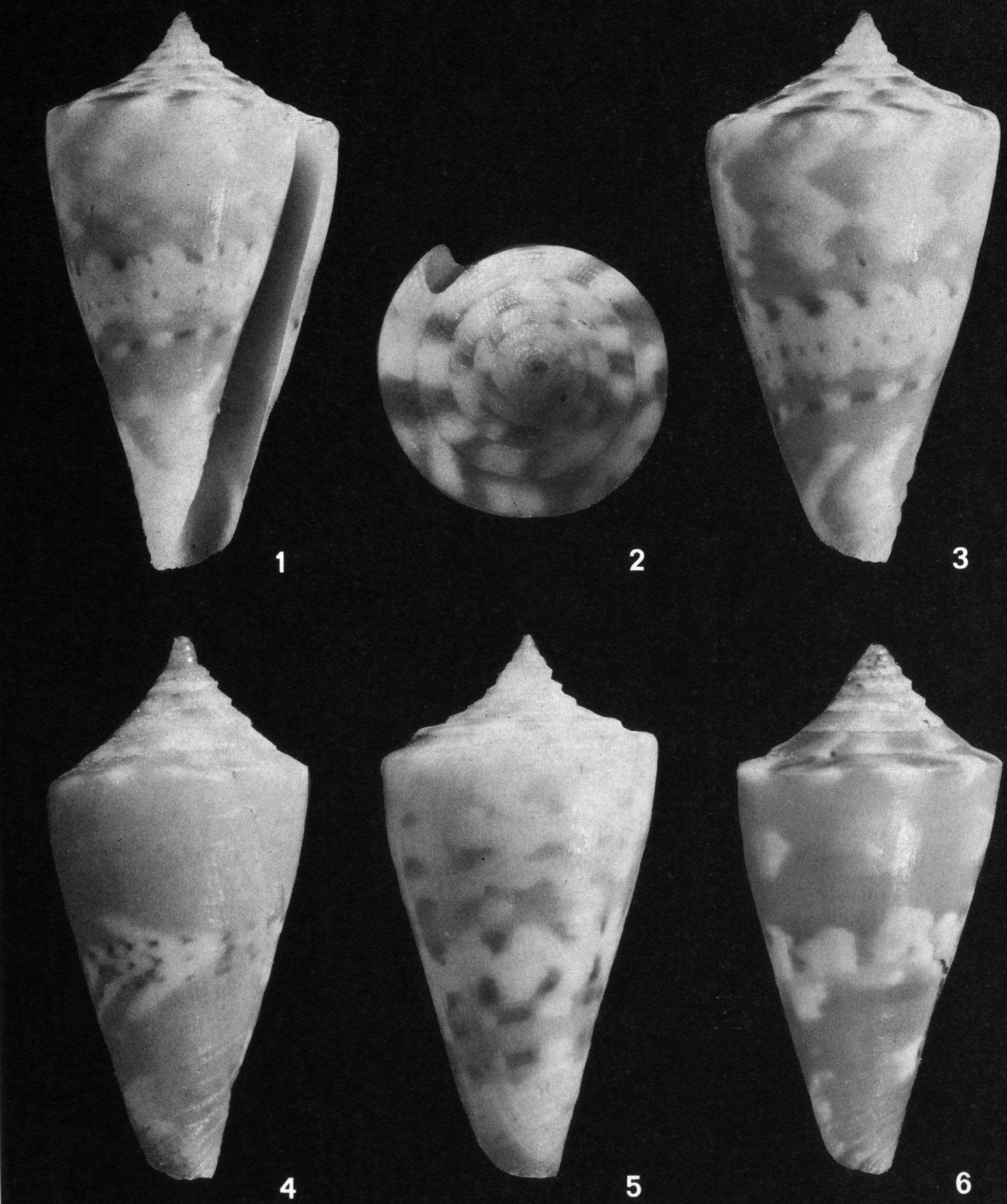

Figs. 1-6. Conus sanderi n. sp.: 1-3, holotype; 4, paratype no. 9; 5, paratype no. 12; 6, paratype no. 15. 
paratypes were deposited in collection Wils (Antwerp), and one paratype each in the Rijksmuseum van Natuurlijke Historie at Leyden (RMNH), Koninklijk Belgisch Instituut voor Natuurwetenschappen at Brussels (IRScNB), and the British Museum (Natural History) at London (BMNH).

TABLE I

Measurements of type material of Conus sanderi.

\begin{tabular}{rrrl}
\hline & $\begin{array}{c}\text { length } \\
(\mathrm{mm})\end{array}$ & $\begin{array}{r}\text { width } \\
(\mathrm{mm})\end{array}$ & collection \\
\hline holotype & 21.1 & 11.2 & ZMA (figs. 1-3) \\
paratype 1 & 22.8 & 11.7 & ZMA \\
2 & 22.3 & 12.1 & ZMA \\
3 & 20.0 & 10.2 & ZMA \\
4 & 20.0 & 9.9 & ZMA \\
5 & 18.2 & 9.8 & ZMA \\
6 & 17.1 & 8.7 & ZMA \\
7 & 16.0 & 8.1 & ZMA \\
8 & 16.0 & 7.8 & ZMA \\
9 & 13.6 & 6.5 & ZMA (fig. 4) \\
10 & 11.3 & 5.3 & ZMA (fig. 10) \\
11 & 11.2 & 5.6 & ZMA \\
12 & 23.2 & 12.0 & Wils (fig. 5) \\
13 & 20.6 & 11.1 & Wils \\
14 & 19.8 & 10.5 & Wils \\
15 & 19.0 & 9.5 & Wils (fig. 6) \\
16 & 19.0 & 9.3 & Wils \\
17 & 14.2 & 7.0 & Wils \\
18 & 20.0 & 10.8 & RMNH \\
19 & 20.0 & 10.5 & IRScNB \\
20 & 22.2 & 11.2 & BMNH \\
\hline
\end{tabular}

D iscussion. - Conus sanderi differs from C. daucus Hwass, 1792, in being smaller, having a higher spire and lacking a pinkish protoconch. It is also different from juveniles of $C$. centurio Born, 1778, which have no striae on the spire, and a grooved last whorl. C. ustickei "Miller" in Usticke, 1959, is more slender and has a straight spire. C. juliae Clench, 1942, of which we examined the holotype, lacks the spiral striae on the spire.

Etymology. - Conus sanderi has been named after Dr. Finn Sander, director of the Bellairs Research Institute.

\section{Conus hunti n. sp.}

Figs. 7-9, 11-14.

Description of holotype. - Shell small, rather slender. Body whorl somewhat concave, shiny. From base to shoulder with about 20 grooves, which become almost smooth on the upper part of the body whorl. Shoulder angulated. Aperture straight and narrow. Spire concave, 8-81/2 whorls. The postnuclear whorls have 3-4 striae, regularly crossed by growth lines. The first $31 / 2$ postnuclear whorls have axial sculpture (tubercle-
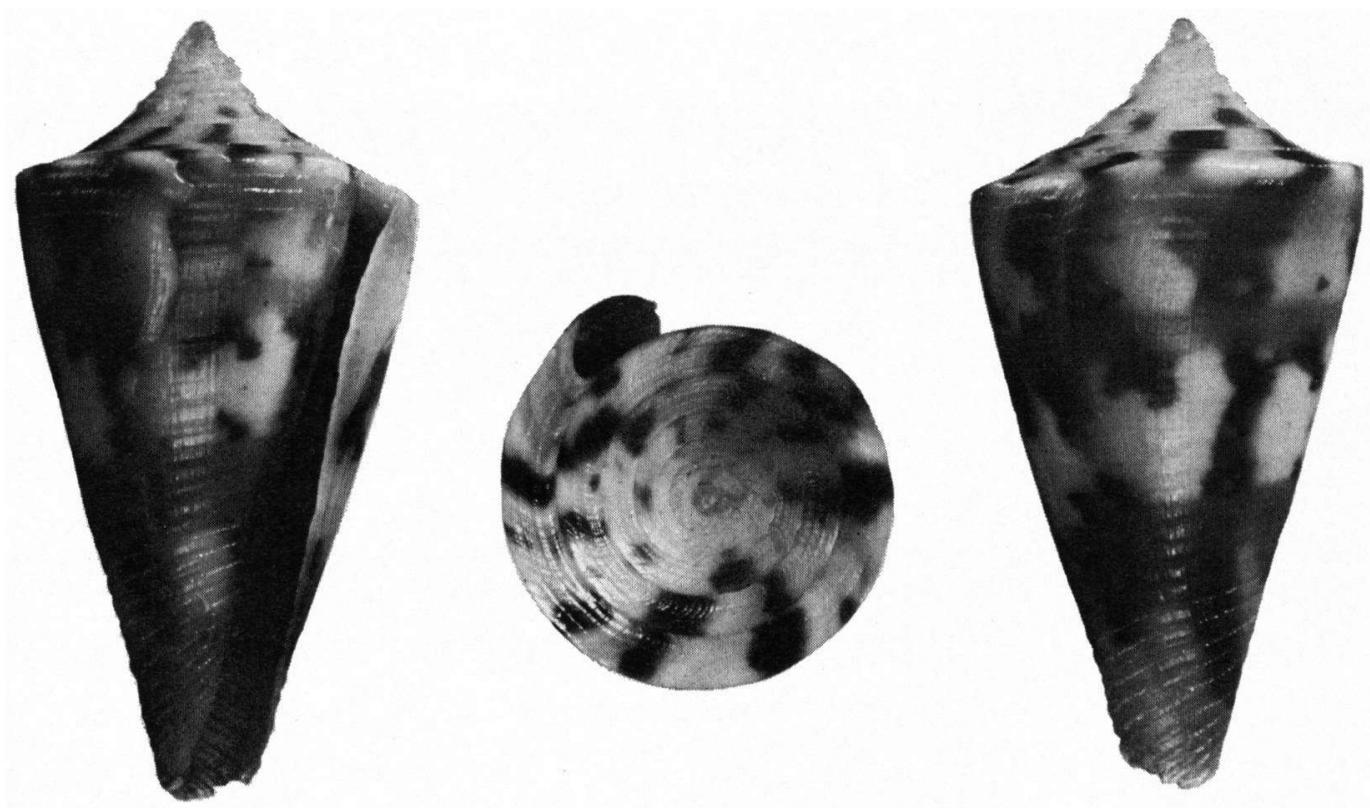

Figs. 7-9. Conus bunti n. sp., holotype. 

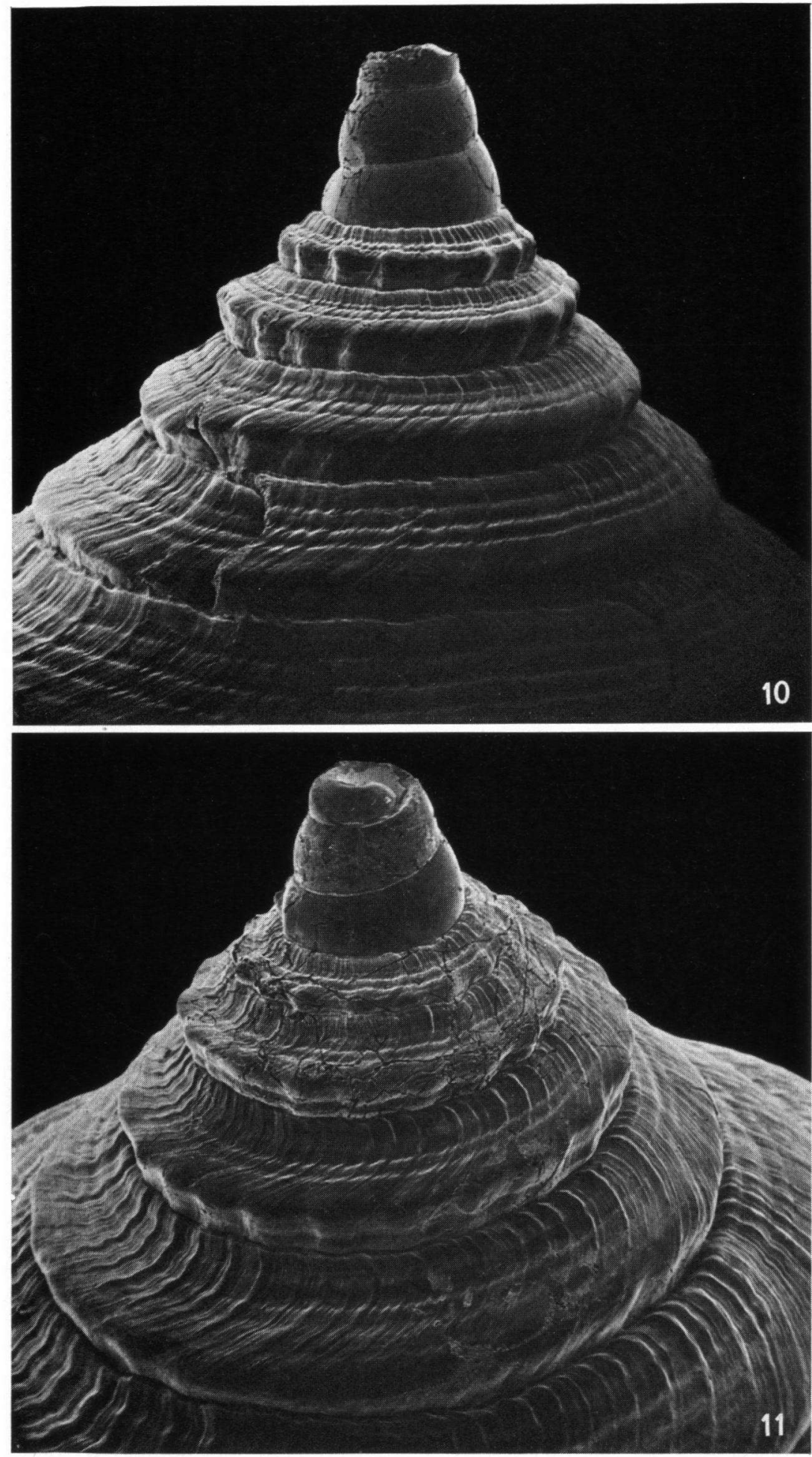

Figs. 10-11. Scanning electron micrographs of top structure $(X 32): 10$, Conus sanderi n. sp., paratype no. 10; 11, C. bunti n. sp., paratype no. 8 . 
like) on the sides, weakening progressively. The protoconch has $21 / 2$ smooth whorls.

Measurements: length $18.6 \mathrm{~mm}$, width $9.9 \mathrm{~mm}$, aperture $15.7 \mathrm{~mm}$.

Colour: The ground colour is light purplish. The last whorl has two brown bands of which the upper one is the narrowest. These bands are crossed by irregular darker brown flames, which continue on the spire. Inside of the aperture translucent, more darker purplish towards the base.

Paratypes. - Shell length up to $23 \mathrm{~mm}$ (table II), rather slender. There are 20-30 spiral grooves on the body whorl, in juveniles these grooves are more pronounced and clearly visible from shoulder to base. Protoconch with 2-21/2 smooth, dirty white nuclear whorls, 7-8 postnuclear whorls of which the first 3-4 have axial sculpture on the sides, weakening progressively. The spire of paratype 8 is represented in fig. 11 by a SEM photograph.

The colour pattern is variable, on the purplish ground colour sometimes only a few dark brown blotches are present. Generally there are two brown bands which are crossed by 5 to 7 irregular brown flames. The periostracum is light brown, translucent and smooth.

TABLE II

Measurements of type material of Conus bunti.

\begin{tabular}{rrrl}
\hline & $\begin{array}{r}\text { length } \\
(\mathrm{mm})\end{array}$ & $\begin{array}{r}\text { width } \\
(\mathrm{mm})\end{array}$ & collection \\
\hline holotype & 18.6 & 9.9 & ZMA (figs. 7-9) \\
paratype 1 & 21.0 & 10.6 & ZMA \\
2 & 20.0 & 11.0 & ZMA \\
3 & 19.0 & 10.0 & ZMA \\
4 & 18.9 & 10.5 & ZMA \\
5 & 17.7 & 9.1 & ZMA \\
6 & 17.5 & 9.9 & ZMA \\
7 & 14.7 & 7.1 & ZMA (fig. 12) \\
8 & 13.9 & 7.2 & ZMA (fig. 11) \\
9 & 23.0 & 12.7 & Wils (fig. 13) \\
10 & 21.0 & 11.1 & Wils (fig. 14) \\
11 & 20.7 & 11.1 & Wils \\
12 & 19.7 & 10.7 & Wils \\
13 & 19.6 & 10.5 & Wils \\
14 & 20.7 & 11.3 & RMNH \\
15 & 17.3 & 9.2 & IRSNB \\
16 & 17.8 & 9.2 & BMNH \\
\hline
\end{tabular}

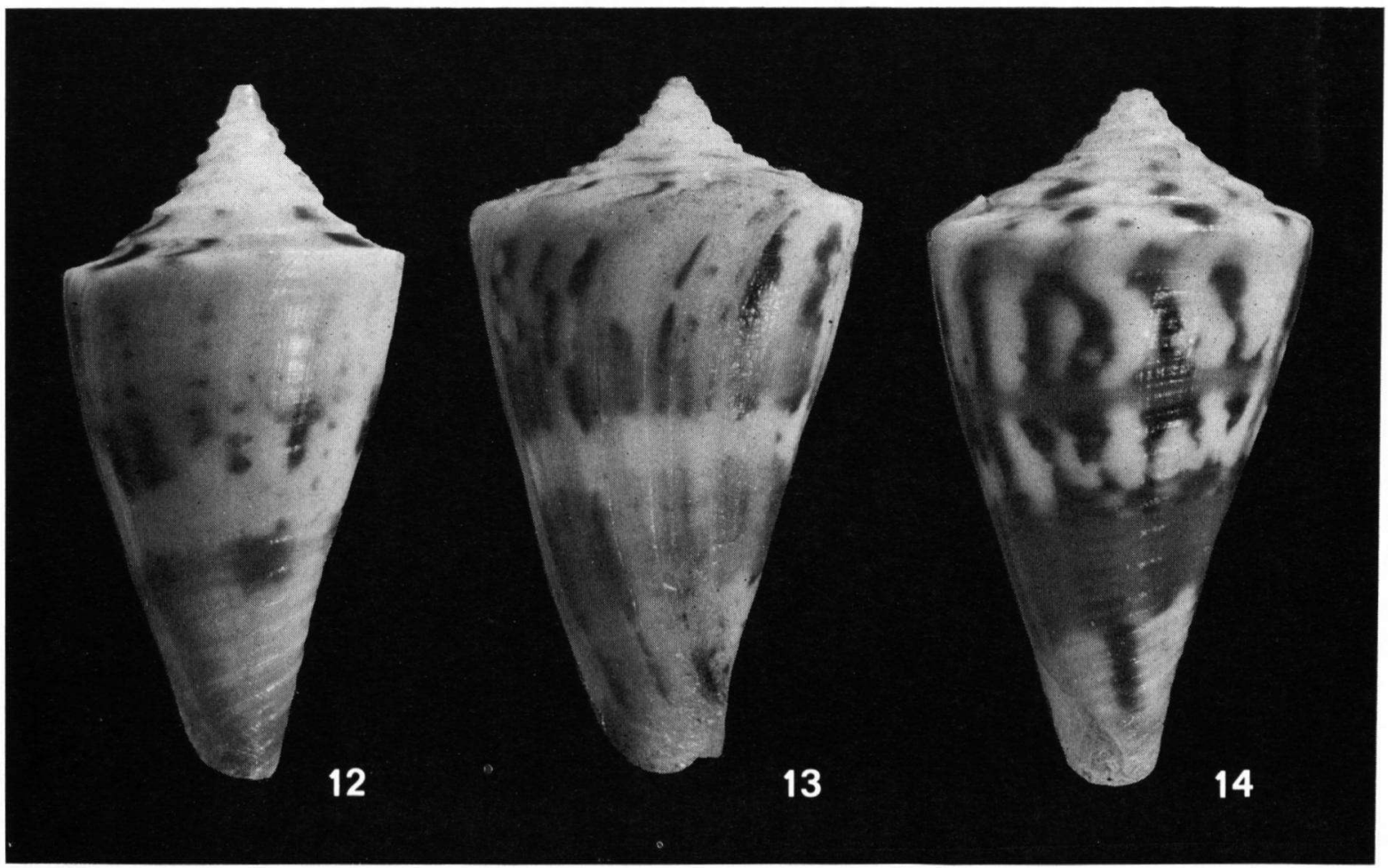

Figs. 12-14. Conus bunti n. sp.: 12, paratype no. 7; 13, paratype no. 9; 14 , paratype no. 10. 
Ty pe locality. - Off St. James, west Barbados, $155-180 \mathrm{~m}$.

Deposition of type material. - The holotype and 8 paratypes are in the collection of the Zoölogisch Museum Amsterdam. Five paratypes in collection Wils (Antwerp), and one paratype each in RMNH, IRScNB, and BMNH.

Discussion. - Conus bunti is different from $C$. sanderi, as it is purplish and has grooves all over the last whorl, whereas $C$. sanderi is yellowish orange and has spiral grooves on the base only. C. villepinii Fischer \& Bernardi, 1857, from the same area, is more slender, becomes larger (to $45 \mathrm{~mm}$ ), and is white with rows of large yellowish brown blotches; the spire is concave to straight, with about 12 grooves on the base and more pronounced striae on the spire whorls.

Et y molog y. - Conus bunti has been named after Mr. David Hunt of Barbados.

\section{ACKNOWLEDGEMENTS}

The authors are grateful to Dr. H. E. Coomans for his advice. The photographs of the shells were made by Mr. L. A. van der Laan (Institute of Taxonomic Zoology). The SEMphotographs of the spire were taken by Mr. C. Bakker at the Laboratorium voor Elektronenmikroskopie, University of Amsterdam.

\section{LITERATURE}

Clench, W. J., 1942. The genus Conus in the Western Atlantic. Johnsonia, 1 (6): 1-40, pls. I-XV.

,- 1951 . The genus Conus in the Western Atlantic. Johnsonia, 2 (32): 363-376, pls. CLXXXI-CLXXXV.

Clench, W. J. \& R. C. Bullock, 1970. The genus Conus in the Western Atlantic. Johnsonia, 4 (48): 372-378, pls. CLXXV-CLXXVIII.

DALL, W. H., 1886. Reports on the results of dredging, under the supervision of Alexander Agassiz, in the Gulf of Mexico (1877-78) and in the Caribbean Sea (187980 ), by the U.S. Coast Survey steamer "Blake", Lieut.Commander C. D. Sigsbee, U.S.N., and Commander J. R. Bartlett, U.S.N., commanding. XXIX. Report on the Mollusca. Part I. Brachiopoda and Pelecypoda. Bull. Mus. comp. Zool. Harv., 12 (6): 171-318, pls. I-IX.

- , 1889. Reports on the results of dredging, under the supervision of Alexander Agassiz, in the Gulf of Mexico (1877-78) and in the Caribbean Sea (1879-80), by the U.S. Coast Survey steamer "Blake", Lieut.-Commander C. D. Sigsbee, U.S.N., and Commander J. R. Bartlett, U.S.N., commanding. XXIX. Report on the Mollusca. Part II. Gastropoda and Scaphopoda. Bull. Mus. comp. Zool. Harv., 18: 1-492, pls. X-XL.

Lozet, J. B. \& C. PÉTron, 1977. Coquillages des Antilles: 1-138 (Editions du Pacifique, Tahiti).

Mol, J.-J. vaN, 1973. Les Conidae du Surinam. Zoöl. Meded. Leiden, 46 (19): 262-268, pls. I-II.

Mol, J.-J. van, B. Tursch \& M. KempF, 1967. Les Conidae du Brésil. Annls. Inst. océanogr., Monaco, 45: 233-255, pls. I-VI.

,$--\&-1971$. Further notes on Brazilian Conidae. Zoöl. Meded. Leiden, 45 (15): 161-166, pl. I.

Nowell-Usticke, G. W., 1968. Caribbean cones from St. Croix and the Lesser Antilles: 1.30 (Livingston Publ. Co., Narbert). 